Contents list available at IJRED website

Int. Journal of Renewable Energy Development (IJRED)

Journal homepage: www.ijred.com

\title{
Potency of Microalgae as Biodiesel Source in Indonesia
}

\author{
Hadiyanto*, Widayat and Andri Cahyo Kumoro \\ Center of Biomass and Renewable Energy, Chemical Engineering Department, Diponegoro University, \\ Jl.Prof Sudharto,SH-Tembalang, Semarang INDONESIA
}

\section{Article history:}

Received January 21, 2012 Received in revised form Feb 8, 2012 Accepted February 17, 2012 Available online

\begin{abstract}
Within 20 years, Indonesia should find another energy alternative to substitute current fossil oil. Current use of renewable energy is only $5 \%$ and need to be improved up to $17 \%$ of our energy mix program. Even though, most of the area in Indonesia is covered by sea, however the utilization of microalgae as biofuel production is still limited. The biodiesel from current sources (Jatropha, palm oil, and sorghum) is still not able to cover all the needs if the fossil oil cannot be explored anymore. In this paper, the potency of microalgae in Indonesia was analysed as the new potential of energy (biodiesel) sources.
\end{abstract}

Keywords: Microalgae, Biodiesel, Biomass, Indonesia, Alga lipid

\section{Introduction}

The rapid depletion of current oil reserve will force Indonesia to explore new energy alternative sources such as renewable energy instead of fossil oil. Currently, the use of renewable energy in Indonesia is only $5 \%$ from total energy mix, which need to be increased to $17 \%$ by 2025 . From this target, $5 \%$ is expected from biomass energy [1].

The development of biofuel in Indonesia shows interesting trend which is mainly from palm oil, corn oil, coconut oil, jatropha, rubber seed oil and nyamplung. However, the utilization of microalgae for biofuel is still under development. Therefore this paper aims to describe the potency of microalgae as biofuel source in Indonesia.

Microalgae is a unicellular photosynthetic organism $(1-400 \mu \mathrm{m})$ that is potential for fine chemicals [2], food additive, immobilized system for extracellular compound, metal bio-sorption, and $\mathrm{CO}_{2}$ bio-fixation. Microalgae utilize light to convert Carbon sources and water into biomass- $\mathrm{CH}_{2} \mathrm{O}$ and oxygen based on following photosynthetic reaction:

$$
\mathrm{CO}_{2}+\mathrm{H}_{2} \mathrm{O}+\text { light } \rightarrow \mathrm{CH}_{2} \mathrm{O}+\mathrm{O}_{2}
$$

The $\mathrm{CO}_{2}$ demand is stoichiometrically about $1.8 \mathrm{~kg}$ $\mathrm{CO}_{2} / \mathrm{kg}$ dry biomass. For microalgae biomass, higher energy efficiencies for converting solar energy into chemical energy can be achieved. Microalgae can convert up to $5 \%$ of the sunlight energy to biomass.
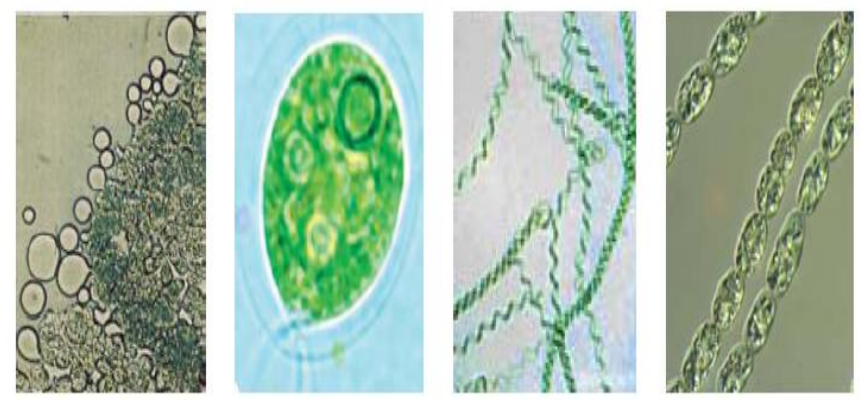

Fig. 1 Type of microalgae

Microalgae have their highest growth efficiencies at illumination intensities of not more than around 100 $\mu \mathrm{E} /\left(\mathrm{m}^{2} \mathrm{~s}\right)$, whereas a sunny tropical day can exhibit values up to $2000 \mu \mathrm{E} /\left(\mathrm{m}^{2} \mathrm{~s}\right)$. If it is compared to other higher plants, microalgae shows higher productivity of oil per unit area of required land as shown in Figure 2.

* Corresponding author: Tel: +62-24-7460058

E-mail: hady.hadiyanto@gmail.com 


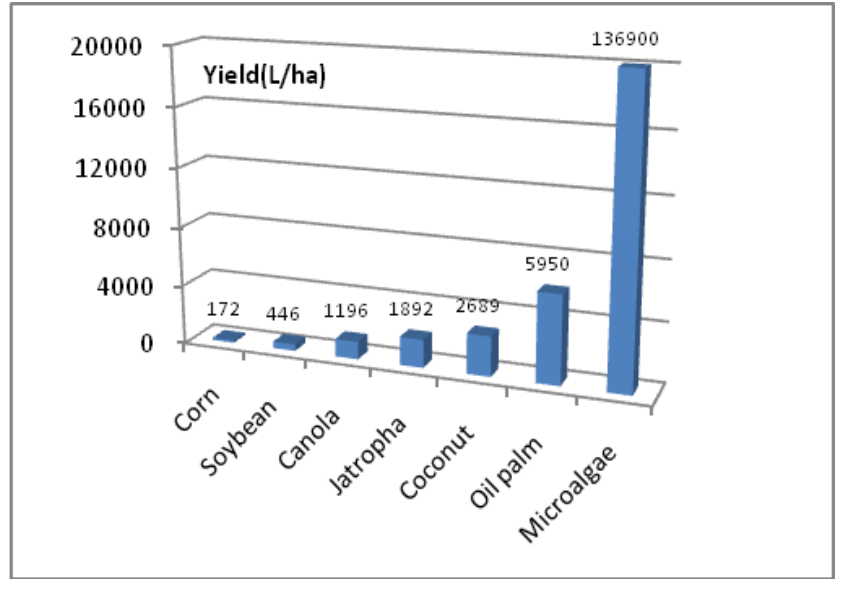

Fig. 2 Microalgae oil productivity compared to other plants

Recently microalgae are used due to its content of lipid, carbohydrate (starch) and protein. Figure 3 shows the direction of biofuel converted from microalgae. Carbohydrate is mainly source for bioethanol production, while lipid for biodiesel. The lipid content of microalgae is shown in Table 1.

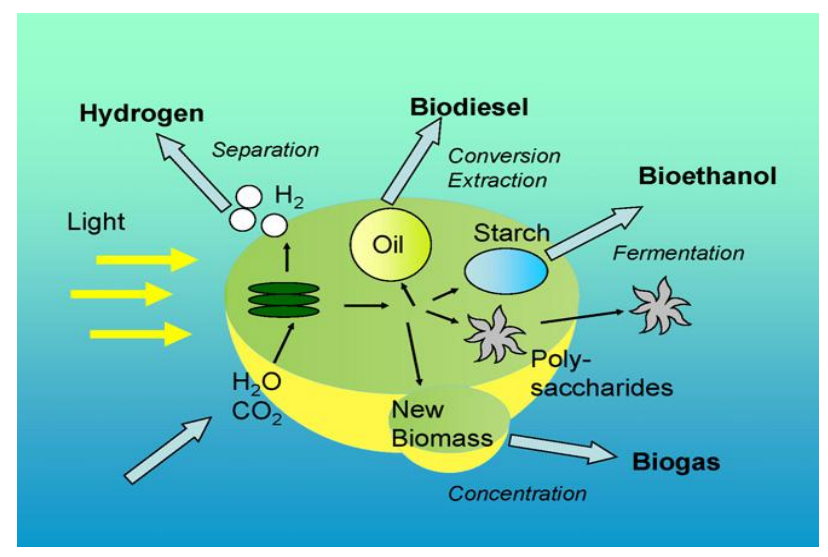

Fig. 3 The potential pathways from microalgae to biofuel

\section{Microalgae Production}

The common approach to produce microalgae is by using open ponds [2]. From this system, up to 15-20 $\mathrm{g} /\left(\mathrm{m}^{2} \mathrm{~d}\right)$ dry biomass can be harvested. However, open ponds have some disadvantages such as that the cultivation depends on water availability, while in another side evaporation will be a significant barrier due to water loss. Furthermore, the water medium must be extremophiles conditions to some extent to avoid contamination by predator organisms.

In addition, mixing and harvesting in an open pond is less effective due to low cell concentration. This leads to non-economically viability for biofuel products from microalgae. However, since the price of oil significantly higher, this option has to be improved to have better microalgae cultivation.
Compared to open pond, photo-bioreactors has advantages in light distribution. In addition, due to closed system, the evaporation can be reduced completely. Another advantage is that the cell density biomass more than $20 \mathrm{~g} / \mathrm{L}$ can be obtained. Contamination in the closed system is likely less so different and more productive species can be produced. The limiting factor of this system is high cost and mixing energy. It was reported that more than $3 \mathrm{~W} / \mathrm{m}^{2}$ needed for operating the cultivation.

Table 1

Oil content of algae [3]

\begin{tabular}{lc}
\hline Microalgae & Lipid content (\%) \\
\hline Botrycoccus Braunii & $25-75$ \\
Chlorella sp & $28-32$ \\
Crypthecodinium cohnii & 20 \\
Cylindrotheca sp. & $16-37$ \\
Dunaliella primolecta & 23 \\
Isochrysis sp. & $25-33$ \\
Monallanthus salina & $>20$ \\
Nannochloris sp. & $20-35$ \\
Nannochloropsis sp. & $31-68$ \\
Neochloris oleoabundans & $35-54$ \\
Nitzschia sp. & $45-47$ \\
Phaeodactylum tricornutum & $20-30$ \\
Schizochytrium sp. & $50-77$ \\
Tetraselmis sueica & $15-23$ \\
\hline
\end{tabular}

\section{The Potency of Microalgae in Indonesia}

Geographically, Indonesia lies on equator where sunlight intensity is high. The major parameter limiting algal production process is climate or temperature. Locations with suitable climate conditions encompass area with annual average temperature of $15^{\circ} \mathrm{C}$ or higher (Figure 4).

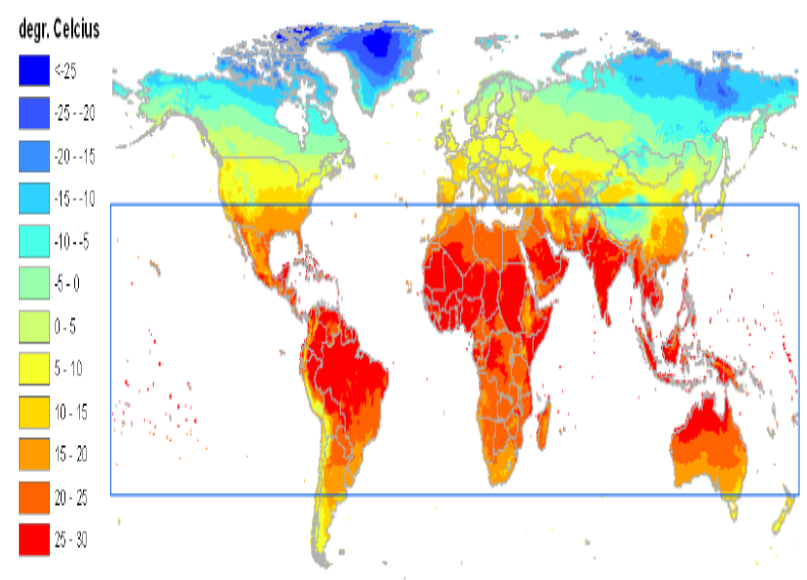

Fig. 4 Suitable climate conditions for microalgae cultivation

The study of microalgae potential in Indonesia has been done recently in Central Java, in particularly at three locations: Panjang Island, Awur Bay and Rembang coast [4]. 


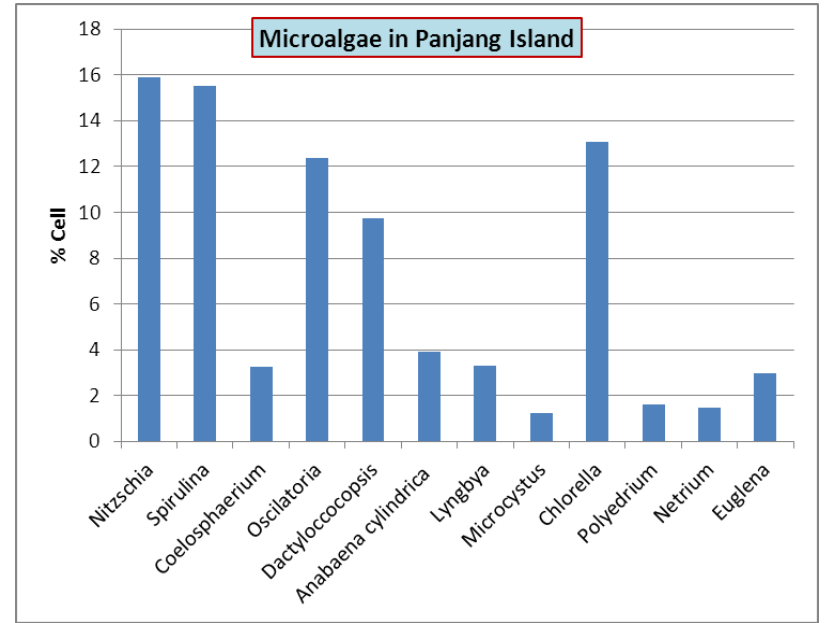

(a)

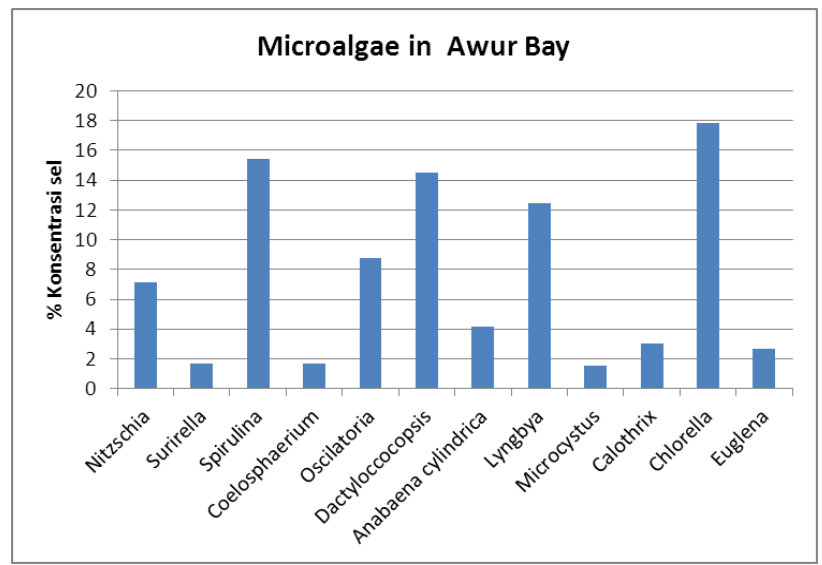

(b)

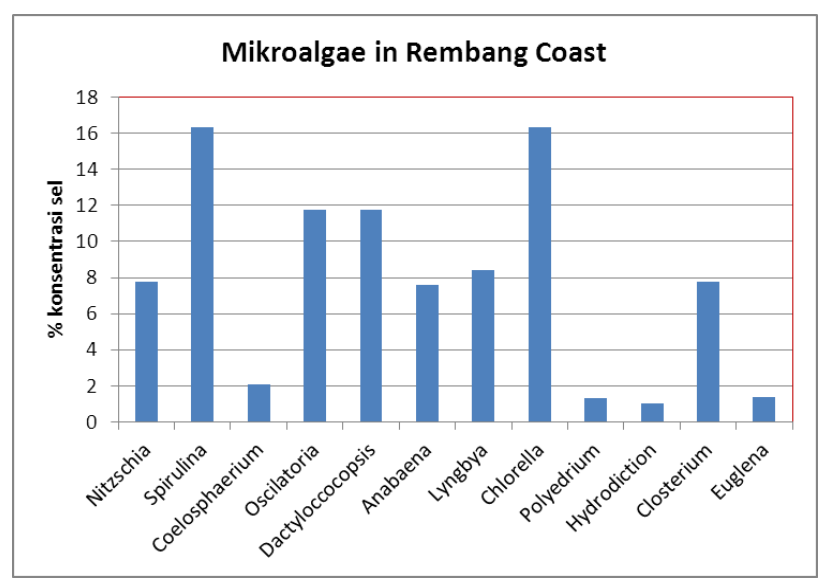

(c)

Fig. 5 Microalgae identification in Central Java coast (a). Panjang island, (b) Teluk awur dan (c). Rembang coast

Figure 5 shows that in Central Java coast, the microalgae are mostly dominated by Nitzschia $s p$., Spirulina sp., Chlorella, Anabaena sp. dan Euglena sp. These five species were analysed for their protein, carbohydrate and lipid contents. It shows that Chlorella sp., Nitzchia sp. and Euglena have higher oil content which can be considered as future biofuel sources (Table 2).
Table 2

Protein, Strach and lipid content of selected microalgae

\begin{tabular}{lccc} 
Chemical Composition & Protein(\%) & Carb(\%) & Lipid(\%) \\
\hline Nitzschia palea & 48 & 23 & 20 \\
Chlorella vulgaris & 58 & 17 & 27 \\
Spirulina platensis & 63 & 14 & 9 \\
Euglena gracilis & 61 & 18 & 20 \\
Anabaena cylindrica & 56 & 30 & 7
\end{tabular}

Chlorella sp. was experienced to be cultivated in a small mini POND system using synthetic medium with following composition: $29.23 \mathrm{~g} / \mathrm{L} \mathrm{NaCl}, 1.105 \mathrm{~g} / \mathrm{L} \mathrm{KCl}$, $11.09 \mathrm{~g} / \mathrm{L} \mathrm{MgSO}_{4} 7 \mathrm{H}_{2} \mathrm{O}, 1.21 \mathrm{~g} / \mathrm{L}$ Tries-base, $1.83 \mathrm{~g} / \mathrm{L}$ $\mathrm{CaCl}_{2} .2 \mathrm{H}_{2} \mathrm{O}, 0.25 \mathrm{~g} / \mathrm{L} \mathrm{NaHCO}_{3}$, and $3.0 \mathrm{~mL}$ of trace metal solution contained $281.3 \mathrm{mg} / \mathrm{L} \mathrm{NaNO}_{3}, 21.2 \mathrm{mg} / \mathrm{L}$ $\mathrm{NaH}_{2} \mathrm{PO}_{4} \mathrm{H}_{2} \mathrm{O}, 16.35 \mathrm{mg} / \mathrm{L} \mathrm{Na}{ }_{2}$ EDTA, $11.8 \mathrm{mg} / \mathrm{L} \mathrm{FeCl}$ $6 \mathrm{H}_{2} \mathrm{O}, 37.5 \mu \mathrm{g} / \mathrm{L} \mathrm{CoCl}_{2} 6 \mathrm{H}_{2} \mathrm{O}, 37.5 \mu \mathrm{g} / \mathrm{L} \mathrm{CuSO}_{4} 5 \mathrm{H}_{2} \mathrm{O}$, $82.5 \mu \mathrm{g} / \mathrm{L} \mathrm{ZnSO}_{4} 7 \mathrm{H}_{2} \mathrm{O}, 22.5 \mu \mathrm{g} / \mathrm{L} \mathrm{Na}_{2} \mathrm{MoO}_{4}, 0.375 \mathrm{mg} / \mathrm{L}$ vitamin $\mathrm{B}_{1}, 0.188 \mu \mathrm{g} / \mathrm{L}$ vitamin $\mathrm{B}_{12}$. The mini pond system was built to mimic real pond system with a ratio L/D=10 (Figure 6).

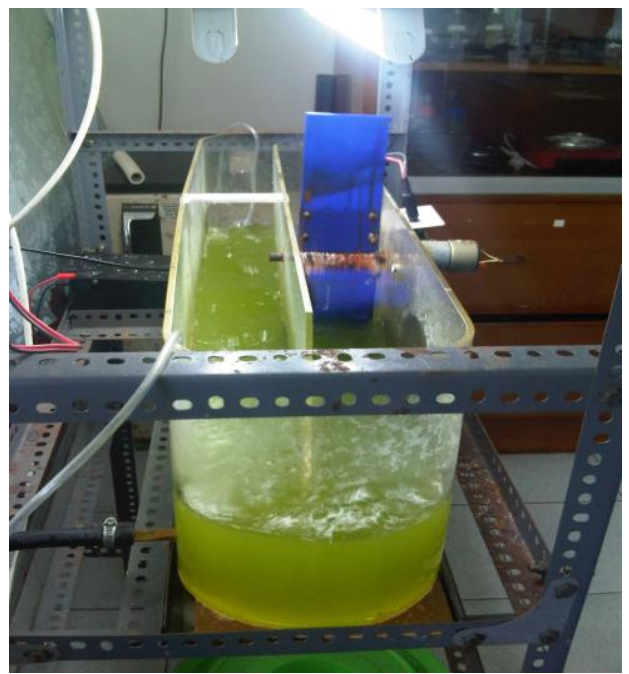

Fig. 6 Mini pond system for algae cultivation

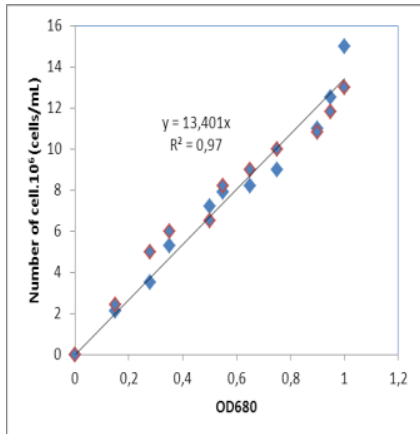

(a)

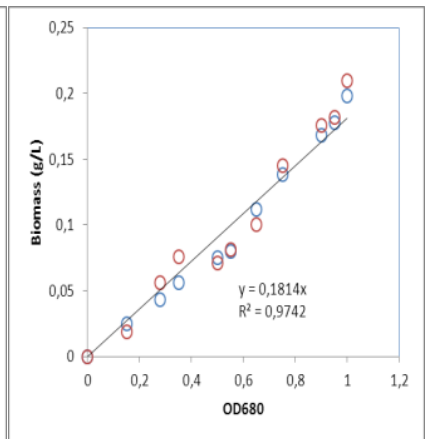

(b)
Fig. 7 Correlation between optical density and number of cell (a) and Optical density and Biomass (b) 
The cultivation of Chlorella has been done within 14 days under temperature and $\mathrm{pH}$ constant. The mixing was generated by a paddle wheel with velocity $10 \mathrm{rpm}$.

$$
\text { CellNumber }(\mathrm{sel} / \mathrm{mL})=13.4 \times 10^{6} \mathrm{OD}_{680}
$$

Figure 7 show the correlation of optical density, number of cell and biomass which then can be transferred into following equations:

$$
\operatorname{Biomasa}(g / L)=0.1814 \cdot O D_{680}
$$

Biomasa $(g / L)=1.35 \cdot 10^{-8}$ Number of cell $(\mathrm{sel} / \mathrm{mL})$

The growth of Chlorella is shown by Figure 8 as function of cultivation time and paddle wheel velocity. It shows that the rotation of paddle wheel give significant of cell growth due to reducing cell sedimentation at the bottom of pond and also to increase the light distribution to the cells $[5,6]$.

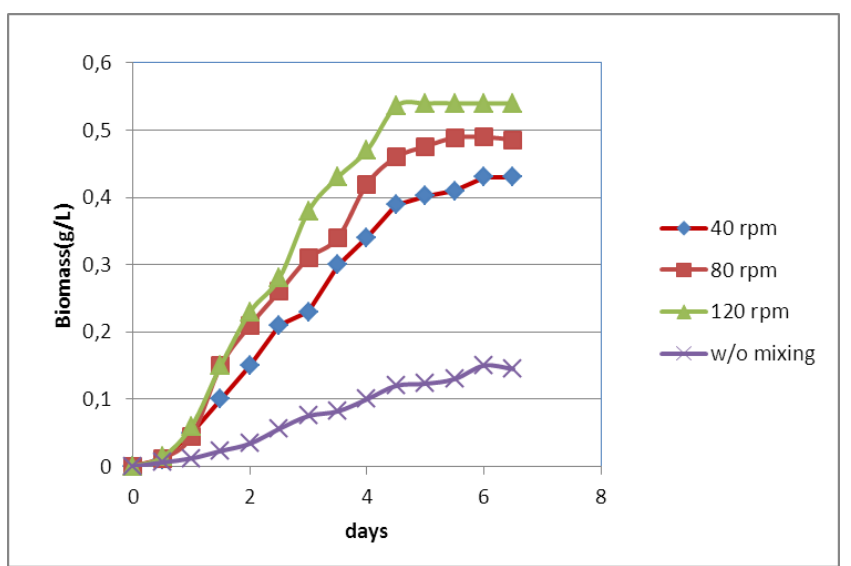

Fig. 8 The growth rate of Chlorella $s p$ in mini pond system.

\section{Microalgae Biomass to Biodiesel}

Conversion of Algae biomass to biodiesel is performed through trans-esterification reaction (Figure 9).

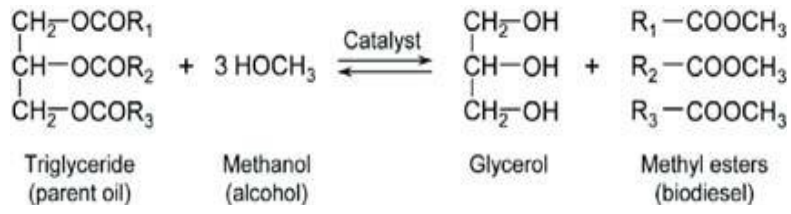

Fig. 9 Esterification reaction of oil to biodiesel

In this reaction, we need 3 moles of alcohol for each mole of triglyceride to produce 1 mole of glycerol and 3 moles of biodiesel. However, to ensure that all triglyceride is converted to biodiesel, the methanol is used excess ( 6 moles). The yield of biodiesel exceeds $89 \%$ on a weight basis.

The characteristic of algae biodiesel is shown in Table 3 while the production is shown in Figure 9.

Table 3

Physical properties algae biodiesel

\begin{tabular}{ll}
\hline Variable & Value \\
\hline Acid number & $0.15-0.4 \mathrm{mg} \mathrm{KOH} / \mathrm{g}$ \\
Density & $0.89 \mathrm{~g} / \mathrm{mL}$ \\
Iod number & $109 \%$ \\
\hline
\end{tabular}
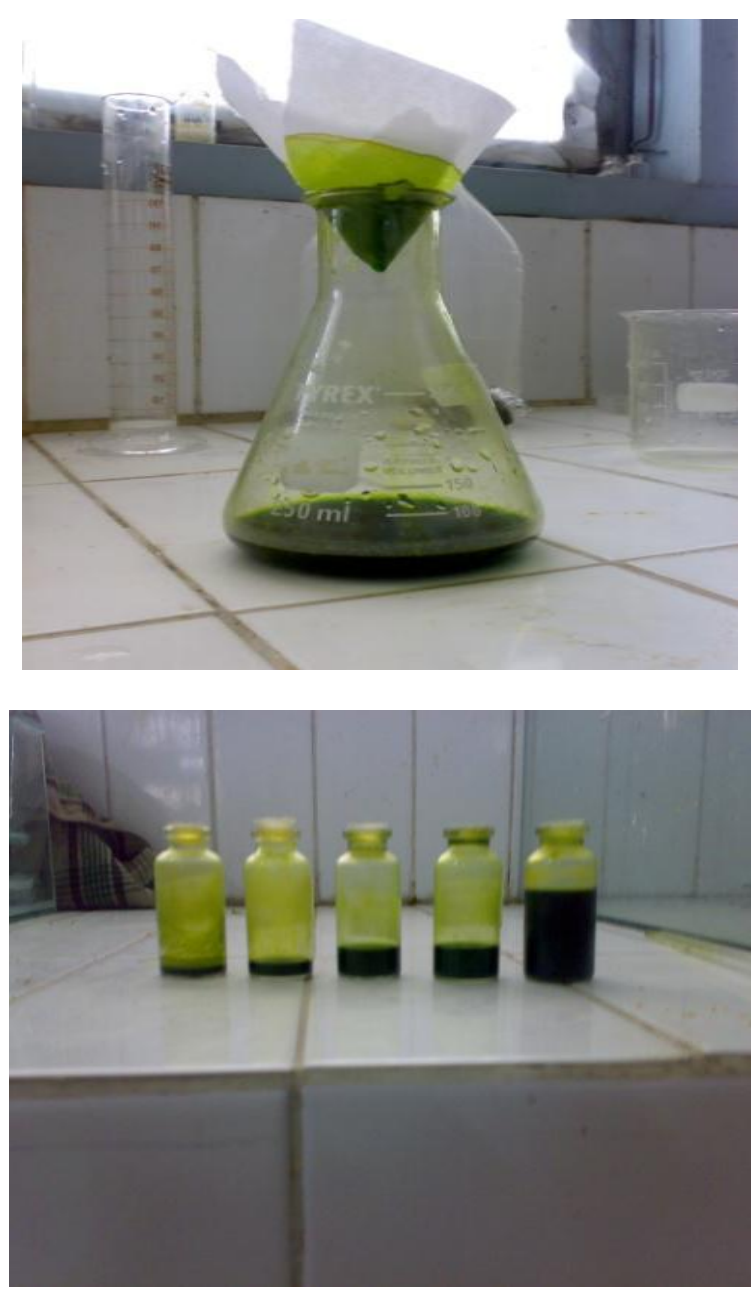

Fig. 9 Biodiesel products from microalgae

\section{Conclusion}

As coastal country, Indonesia has high potential for microalgae cultivation. The microalgae are considered for biofuel production. The microalgae which have high oil content (20-30\%) are: Nitzschia palea (23), Chlorella vulgaris (27), Euglena gracilis (20) which were identified at Panjang island, Teluk Awur, and Rembang coastal. 


\section{Acknowledgement}

This research is supported by research grant of Hibah Kompetitif Prioritas Nasional Batch II Tahun 2009 Number SPK: 304/SP2H/PP/DP2M/VI/ 2009.

\section{References}

[1] Menteri Sumber Daya Energi dan Mineral, (2006), National Energy Management 2006-2025. Jakarta.
[2] Borowitzka MA (1999) Pharmaceuticals and agrochemicals from microalgae. In: Cohen Z, editor. Chemicals from Microalgae. Taylor \&Francis. pp: 313-352.

[3] Chisti Y (2007) Biodiesel from Microalgae. Biotechnology Advances 25:294-306.

[4] Hadiyanto, Samidjan I, Kumoro AC, Silviana (2010) Production of High Density Biomass in Open Pond System. Proceeding Seminar Teknik Kimia Kejuangan UPN Jogjakarta.

[5] Richmond A (2004) Biological Principles of Mass Cultivation. In: Richmond A, editor: Handbook of microalgae culture: Biotechnology and applied phycology. Blackwell. pp: 125-177.

[6] Richmond, A (2004) Principles for Attaining Maximal Microalgal Productivity in Photobioreactors: An Overview. Hydrobiologia 512: 33-37. 